\title{
Acceptability and Test the Levels of Protein in a Biscuit With the Substitution of Milkfish Flour (Chanos Chanos Forskal)
}

\author{
Zidni Ilman Navia*, Adi Bejo Suwardi \\ Department of Biology, Faculty of Engineering \\ Samudra University \\ Aceh, Indonesia \\ *navia@unsam.ac.id
}

\begin{abstract}
Biscuits are a form of a very common and community-favoured dry snack. Other nutrients, such as protein, may increase the nutritional content of biscuits that are dominated by carbohydrate sources. Fish is a type of protein that's rich. The aim of the study was to determine the protein content and acceptability of milkfish (Chanos chanos) flour replacement biscuits. This method of study is experimental with improving the process and one control twice in a randomized design. Milkfish flour replacements are $0 \%, 5 \%, 10 \%$ and 15 $\%$. By the Kjeldahl process, protein content and acceptance were obtained and checked on 30 panellists. One Way ANOVA and Kruskal Wallis, accompanied by DMRT, were used to evaluate the statistical test of protein content and acceptance. The ANOVA test reveals the 0.000 -value of the halo protein biscuits. The results of the Kruskal Wallis test showed the colour, aroma, taste, texture, and overall value of the halo biscuits at 0.000 . Best protein content with a $15 \%$ substitution rate. The most common biscuit for the panellists is the $\mathbf{5 \%}$ substitution of milkfish flour. The replacement of milkfish flour is affected by protein content and the acceptability of biscuits.
\end{abstract}

Keywords—biscuit, fish flour, protein content, receptivity

\section{INTRODUCTION}

Aceh has high biodiversity, such as native fruit plants [1-4], herbs and spices [5], and tuberous plants [6] many of which have been used by local communities as medicinal plants $[1,7,8]$, ancient rituals [9], garden plant and animal feed [10], and construction materials [11]. The Acehnese people also use plants for their livelihoods and make efforts to conserve plant biodiversity [12,13]. In addition, Aceh also has a high level of fishing and marine wealth, making it one of the Minneapolitan regions, especially in the East Aceh District. According to the map of aquaculture development centres, Aceh Province is one of the 15 provinces that produce aquaculture production on the basis of key commodities such as shrimp, snapper, and milkfish for the period 2011-2015 [14]. Fish is known to have a high protein content [15]. One type of fish that is very common in Indonesia and popular for consumption is Bandeng or milkfish.

\author{
Seprianto \\ Department of Chemistry Education, Faculty of Training \\ and Education \\ Samudra University \\ Aceh, Indonesia
}

Nutritional problems in toddlers are the result of unbalance in food intake, both macro and micronutrients [16], such as iron and iodine, which are still common. Biscuits are a form of very common and community-favoured dry snacks, it is estimated that 13.4 percent of the population of Indonesia eat biscuits more than once a day [17]. Biscuits have a high nutritional value of carbohydrates but relatively low content of protein. The nutritional value of biscuits per 100 grams is 458 kcal of energy, 6.9 grams of protein, 14.4 grams of fat, and 75.1 grams of carbohydrate [18]. The nutritional content of biscuits, which are dominated by carbohydrate sources, can increase the content of certain other nutrients, including proteins. The protein content of biscuits can be improved by substituting proteins for food sources, including milkfish.

The findings of the nutritional content study of milkfish have a high source of protein [19]. The protein content in milkfish was the highest at $24.18 \%$ [19], while mackerel fish was $19.38 \%$, catfish $17.7 \%$, and tilapia $12.46 \%$ [20]. Milkfish flour substitution biscuits may be a choice for providing additional food sources of protein for toddlers. The aim of this study was to examine the effect of substitution for milkfish flour on the protein content and the acceptability of biscuits.

\section{MATERIALS AND METHODS}

This type of study is a type of experiment that aims to determine the effect of flour replacement on protein content and acceptability of biscuit. The study was performed at the Syiah Kuala University Food Laboratory in September-October 2020

\section{A. Materials and Tools}

Fresh milkfish is the substance used in the manufacture of milkfish flour. The products used in the manufacture of biscuits are milk-fish flour, wheat flour, sugar, egg yolk, margarine, and vanilla. Materials used for protein content analysis include condensed sulphuric acid, catalyst (Na2SO4:HgO), $\mathrm{NaOH} \mathrm{Na}$ 
solution, $0.02 \mathrm{~N} \mathrm{HCl}$ solution, 4 percent boric acid, $\mathrm{BCG}+$ $\mathrm{MR}$, Aquades.

Tools used in this analysis were: basin, knife, steamer, microwave, cabinet dryer, grinder, 60 mesh sieve, mixer, automated scale, pan, spoon, scissors, spatula, baking sheet, mold, oven, $50 \mathrm{ml}$ Kjeldahl flask, Kjeldahl distillation equipment, $100 \mathrm{ml}$ Erlenmeyer, $10 \mathrm{ml}$ measuring cup, dropper pipette, $50 \mathrm{ml}$ biuret, electric stove, analytical scale, steam hood, stationery, and acceptability forms.

\section{B. Making a Flour of Milkfish}

The stage of making fish flour, that is, the fish, is washed and then steamed at $100^{\circ} \mathrm{C}$ for 30 minutes, filed, dried at $50^{\circ} \mathrm{C}$ for 16 hours and 24 hours, milled, and sifted by 60 wires.

\section{Making Milkfish Biscuits}

Making milkfish biscuits i.e., milkfish flour $(0 \%, 5 \%, 10 \%$, and $15 \%)$, wheat flour $(100 \%, 95 \%, 90 \%$ and $85 \%$.), refined sugar (50 grams), egg yolk (30 grams), margarine (50 grams) and vanilla (1 gram). Egg yolk, sugar, and margarine are combined with a blender until blended and soft, then add vanilla, then add flour and wheat flour to the dough and combine until creamy, moistened, and baked at $160^{\circ} \mathrm{C}$ for 25 minutes.

\section{Protein Level Analysis}

Analysis of protein content was done by using the Kjeldahl method while fat was measured by using Soxhlet [21]. Water content was determined by using the oven method. Meanwhile, Atomic Absorption Spectrophotometry method was used to calculate calcium level.

\section{E. Acceptability Test}

Acceptance of biscuits was obtained by organoleptic research by 30 people who had been quite educated. Panellists gave their answers by providing a ranking on the favourite survey form on a scale of 7 to 1 . Scale 7 is the very liking scale and scale 1 is very dislike. Each treatment has been given a code namely P1 (without substitution), P2 (substitution of 5\%), P3 (substitution of 10\%), and P4 (substitution of 15\%).

\section{F. Data Analysis}

Examination of protein content using the One Way Anova test and acceptance using the Kruskal Wallis test with a substantial level of $95 \%$ using SPSS 13 and if there is an impact, continue with the Duncan Multiple Range Test (DMRT). Presentation of data in the form of charts, tables, and narratives.

\section{RESULTS AND DISCUSSION}

\section{A. Crude Protein}

The results of the statistical analyses carried out indicate that there is a substantial variation in the protein content of milkfish biscuits. The average protein content at $0 \%$ substitution was the lowest protein content, i.e., 11,59 grams per 100 grams, and the highest protein content was contained in biscuits with $15 \%$ milkfish flour substitution, i.e., 17,31 grams per 100 grams (Figure 1). This study suggests that the higher the substitution of milkfish powder, the higher the protein content of the biscuits.

Based on the One-Way ANOVA statistical test this shows that there is a significant effect on the substitution of milkfish flour on protein content. The results can be seen that there is a significant difference between each treatment (Figure 1). In the process of making milkfish flour, the fish is steamed first, this is because it reduces the water content and fat content in food. The method of processing fish by steaming has a high protein content compared to boiling and has decreased protein content less than fresh food [22].

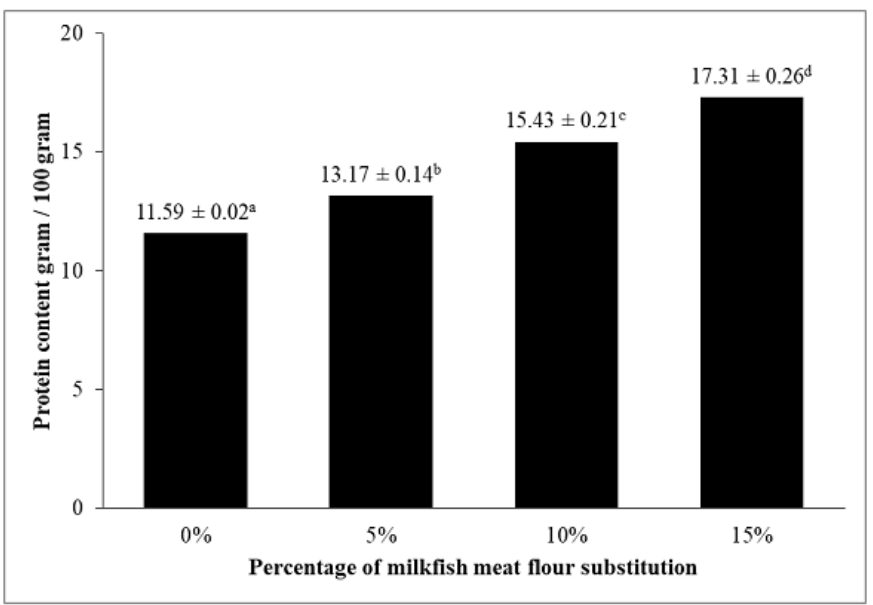

Fig. 1. Milkfish biscuit protein level test results.

Based on Figure 1, the highest protein value of milkfish biscuits is $15 \%$ in the milkfish flour substitute. Thus, the higher the substituted milkfish flour, the higher the protein level of the milkfish biscuits. This study is in line with Domili [21] also indicates the same thing concerning the replacement of mackerel fish flour for protein content, the higher the substitution of mackerel fish flour. The minimum protein content for biscuits according to the Indonesian National Standard is $5 \%$. The protein content of milkfish meat flour substitute biscuits was $13.17 \%-17.31 \%$. This shows that the protein content of milkfish biscuits has met the Indonesian National Standard.

\section{B. Acceptability of Biscuits}

Acceptability is the measure of the preferred standard of the panellist for mackerel biscuit products and is measured based on organoleptic properties. The organoleptic properties assessed include colour, aroma, taste, texture, and overall preference. The acceptability of milkfish biscuits with milkfish flour substitutions can be found in Table 1 below. 


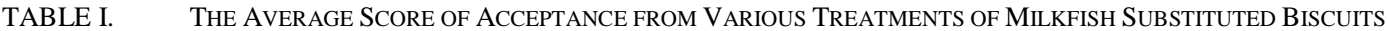

\begin{tabular}{|l|l|l|l|l|l|}
\hline $\begin{array}{c}\text { Percentage of Milkfish } \\
\text { Flour Substitution }\end{array}$ & \multicolumn{1}{|c|}{ Colour } & \multicolumn{1}{|c|}{ Aroma } & \multicolumn{1}{|c|}{ Taste } & \multicolumn{1}{|c|}{$\begin{array}{c}\text { Overall } \\
\text { Preference }\end{array}$} \\
\hline $0 \%$ & $5.40 \pm 0.675^{\mathrm{c}}$ & $5.13 \pm 0.730^{\mathrm{b}}$ & $5.10 \pm 0.607^{\mathrm{bc}}$ & $5.17 \pm 0.834^{\mathrm{c}}$ & $5.27 \pm 0.583^{\mathrm{bc}}$ \\
\hline $5 \%$ & $5.27 \pm 0.450^{\mathrm{c}}$ & $5.23 \pm 0.568^{\mathrm{b}}$ & $5.43 \pm 0.568^{\mathrm{c}}$ & $5.47 \pm 0.507^{\mathrm{c}}$ & $5.40 \pm 0.621^{\mathrm{c}}$ \\
\hline $10 \%$ & $4.80 \pm 0.761^{\mathrm{b}}$ & $4.97 \pm 0.809^{\mathrm{b}}$ & $4.87 \pm 0.571^{\mathrm{b}}$ & $4.77 \pm 0.679^{\mathrm{b}}$ & $5.00 \pm 0.455^{\mathrm{b}}$ \\
\hline $15 \%$ & $3.67 \pm 1.124^{\mathrm{a}}$ & $3.27 \pm 0.785^{\mathrm{a}}$ & $3.70 \pm 0.952^{\mathrm{a}}$ & $3.53 \pm 1.008^{\mathrm{a}}$ & $3.57 \pm 0.817^{\mathrm{a}}$ \\
\hline Score $\rho$ & 0 & 0 & 0 & 0 & 0 \\
\hline
\end{tabular}

Note: Different notations show significant differences in the results of Duncan's test analysis

The analyses of the acceptance statistical test were not normally distributed $(<0.05)$ so that the Kruskal Wallis test was used (Table 1). The results of the test revealed that there was an impact on the acceptability of milkfish biscuits on colour, aroma, taste, texture, and overall preference. The following is the definition of the acceptability of milkfish biscuits, which includes colour, aroma, flavour, texture, and overall preference.

Colour is one of the most critical influences in the acceptance or rejection of the product due to the first impression made by the panellists [22]. The colour of the biscuits is determined by the ingredients in the biscuits. In general, the colour of biscuits varies from light brown (yellow) to brown. The findings of the panellists' acceptance test for the most favoured colour of biscuit were $0 \%$ with an average of 5.67. While the lowest was milkfish biscuits with $15 \%$ milkfish meat flour substitute, which had an average of 3.89. Milkfish biscuits with 0 percent treatment have a light brown (yellow colour and are favoured by the panellists. Meanwhile, the colour of the biscuits, with $5 \%, 10 \%$, and $15 \%$, tended to be brownish yellow to brown. Fish flour allows the colour of the biscuits to darken due to a mallard reaction, which is a nonenzymatic browning reaction due to the reaction between the sugar reduction and the amino acid-free or protein-free amine groups [23]. This study is consistent with research by Mervia [24], African catfish flour the more fish flour substitutions, the darker the colour of the biscuit.

Aroma plays an important part in odour testing, and it will offer an assessment of whether or not the product is liked. The results of the most preferred aroma acceptance test were milkfish biscuits with a 5\% replacement of milkfish meat flour with an average value of 5.61. In the meanwhile, the approval of the scent that was least enjoyed by the panellists was milkfish biscuits with a 15\% replacement for milkfish fish flour with an average rating of 3.67. Centred on the Kruskal Wallis test, which reveals that there is an effect on the aroma of milkfish biscuits of the replacement of milkfish meat flour. Based on the results of the statistical test, the results revealed that the milk-fish biscuits were significantly different which had been substituted by $15 \%$. This is because the more milkfish meat replacements, the lower the fragrance approval because the prevailing aroma is the fishy aroma. The scent of milkfish biscuits is caused by the substitution of milkfish meat flour. This is consistent with the Neli [22] research on the substitution of mackerel, the higher the concentration of fish flour applied to the biscuit recipe, the lower the average value of biscuit aroma acceptance.
The result of the most favoured taste approval test was milkfish biscuits with a 5\% substitution of milkfish meat flour with an average value of 5.59. Based on the Kruskal Wallis test, which indicates that the replacement of milk-fish meat flour affects the flavour of milk-fish biscuits. The findings revealed that the flavour of the $0 \%$ substituted milkfish biscuits did not differ significantly from that of the 5\% substituted and $10 \%$ substituted milkfish meat flour but was noticeably different from that of the $15 \%$ substitution. The $5 \%$ substituted milkfish biscuits are different from the $10 \%$ substitutions and the $10 \%$ substituted milkfish biscuits are different from the $15 \%$ substitutions. This is because the further replacement of milkfish meat flour allows the flavour of milkfish biscuits to have a more distinctive taste of fish such that it is less enjoyed by the panellists. This is consistent with the research by Neli et al. [22] on the formulation of snakehead fish flour-related biscuits, namely, the higher the replacement of snakehead fish, the lower the approval by panellists of the texture of snakehead fish biscuits.

The overall evaluation is used to assess the reaction of the panellist to the characteristics of organoleptic consistency such as colour, aroma, taste, texture, and overall food products. The results of the overall preference acceptance test for milkfish biscuits with 5\% replacement of milkfish meat flour with an average value of 5.52 were the most favoured (Table 1). Based on the findings of the study, the overall choice for milkfish biscuits that were not substituted for milkfish meat flour was not substantially different from those substituted for 5\% and $10 \%$ milkfish meat flour but differed from that of milkfish biscuits that were substituted for $15 \%$ milkfish meat flour.

The development of biscuit products containing milkfish meals as an alternative to offering supplementary protein sources for toddlers may be a viable option. Babies and toddlers need source protein for cell growth and brain function, as well as protection against infection [23].

\section{CONCLUSION}

The highest protein content of milkfish biscuits with milkfish meat flour substitution is $15 \%$ milkfish meat flour substitution, 17.31 grams / 100 grams and the lowest is 5\% milkfish meat flour substitution, 13.17 grams / 100 grams. The acceptability of milkfish biscuits with milkfish meat flour substitution on colour, aroma, taste, texture, and overall preference, the most preferred is a biscuit with $5 \%$ milkfish meat flour substitution and the less preferred biscuit is $15 \%$ milkfish meat flour substitution. There is an effect of 
substitution of milkfish meat flour on the protein content of milkfish biscuits, namely the higher the substitution of milkfish meat flour, the higher the protein content of milkfish biscuits. There is an effect of the substitution of milkfish meat flour on the acceptability of milkfish biscuits.

\section{ACKNOWLEDGMENTS}

We are grateful to all people in the studied villages for their kind hospitality and share of knowledge. We are also grateful that the University of Samudra, Aceh, Indonesia has supported this study for its Excellent Basic Research.

\section{REFERENCES}

[1] A.B. Suwardi, Z.I. Navia, T. Harmawan, S. Syamsuardi, and E Mukhtar, "The diversity of wild edible fruit plants and traditional knowledge in West Aceh region, Indonesia," J Med Plants, vol. 7, no. (4), pp. 285-290, 2019.

[2] Z.I. Navia and T. Chikmawati, "Durio tanjungpurensis (Malvaceae), a new species and its one new variety from West Kalimantan, Indonesia," Bangladesh Journal of Botany, vol. 44, no. (3), pp. 429-436, 2015.

[3] A.B. Suwardi, Z.I. Navia, T. Harmawan, N. Nuraini, S. Syamsuardi and E. Mukhtar, "Ethnobotany, nutritional composition and sensory evaluation of Garcinia from Aceh, Indonesia," Mater Sci Eng, vol. 725, no. (1), pp. 012064, 2020.

[4] Z.I. Navia, A.B. Suwardi, T. Harmawan, S. Syamsuardi and E. Mukhtar, "The diversity and contribution of indigenous edible fruit plants to the rural community in the Gayo Highlands, Indonesia," J Agric Rural Dev Trop Subtrop, vol. 121, no. (1), pp. 89-98, 2020.

[5] Z.I. Navia, D. Audira, N. Afifah, K. Turnip, N. Nuraini and A.B Suwardi, "Ethnobotanical investigation of spice and condiment plants used by the Taming tribe in Aceh Indonesia," Biodiversitas, vol. 21, no. (10), pp. 4467-4473, 2020

[6] A.B. Suwardi, I. Indriaty and Z.I. Navia, "Nutritional evaluation of some wild edible tuberous plants as an alternative foods," Innovare J Food Sci, vol. 6, no. (2), pp. 9-12, 2018.

[7] Z.I. Navia and A.B. Suwardi, "The importance of tropical edible fruit plants for tribal communities in East Aceh region, Indonesia," In IOP Conference Series: Earth and Environmental Science, vol. 637, no. 1, pp. 012003, 2021. IOP Publishing.

[8] A.B. Suwardi, M. Mardudi, Z.I. Navia and M. Baihaqi, "Documentation of medicinal plants used by Aneuk Jamee tribe in Kota Bahagia Subdistrict, South Aceh, Indonesia," Biodiversitas, vol. 22, no. (1), pp. 6-15, 2021.

[9] I.H. Sutrisno, B. Akob, Z.I. Navia, N. Nuraini and A.B. Suwardi, "Documentation of ritual plants used among the Aceh tribe in Peureulak
East Aceh District Indonesia,” Biodiversitas, vol. 21, no. (10), pp. 4990 4998, 2020

[10] E. Elfrida, A. Mubarak and A.B. Suwardi, "The fruit plant species diversity in the home gardens and their contribution to the livelihood of communities in rural area," Biodiversitas, vol. 21, no. (8), pp. 36703675,2020

[11] M.A. Ritonga, S. Nurchalidah, K. Karmiati, Z.I. Navia and A.B Suwardi, "Tracing the Variety of Bamboo Species in Langsa City, Aceh," Al-Hayat: Journal of Biology and Applied Biology, vol. 3, no. (1), pp. 8-14, 2020.

[12] A.B. Suwardi, Z.I. Navia, T. Harmawan, S. Syamsuardi and E. Mukhtar, "Ethnobotany and conservation of indigenous edible fruit plants in South Aceh, Indonesia," Biodiversitas, vol. 21, no. (5), pp. 1850-1860, 2020.

[13] A.B. Suwardi, Z.I. Navia, T. Harmawan, S. Syamsuardi, E. Mukhtar, "Wild edible fruits generate substantial income for local people of the Gunung Leuser National Park, Aceh Tamiang Region," Ethnobot Res Appl, vol. 20, pp. 1-13, 2020.

[14] Ministry of Maritime Affairs and Fisheries, Map of Aquaculture Production Centers in 2015. Jakarta: Directorate of Production and Cultivation Businesses, 2016.

[15] A. Nuraeni, I. Rostini, Y. Dhahiyat and R.I. Pratama, "Milkfish bone flour fortification as a source of calcium on donut preference level," Global Scientific Journals, vol. 8, no. (4), pp. 269-277, 2020.

[16] S. Widodo and S. Sirajuddin, "Biscuit formulation with substitution of brown rice flour," Journal of Business on Hospitality and Tourism,vol. 5, no. (2), pp. 159-168, 2019.

[17] Ministry of Health RI, Basic Health Research; RISKESDAS. Jakarta Balitbang Ministry of Health RI, 2013.

[18] Ministry of Health of the Republic of Indonesia, List of Food Ingredients Composition. Jakarta: PERSAGI, 2000.

[19] S. Malle, A.B. Tawali, M.M. Tahir and M. Bilang, "Nutrient composition of milkfish (Chanos chanos, Forskal) from Pangkep, South Sulawesi, Indonesia,” Mal J Nutr, vol. 25, no. (1), pp. 155-162, 2019.

[20] AOAC, Official Methods of Analysis. Washington DC: AOAC, 2005.

[21] I. Domili, R. Labatjo, L.A. Ntau, M.A. Anasiru and F.Y. Arbie, "Quality test of long-jawed mackerel (rastrelliger sp.) fish flour," Food Research, vol. 4, no. (3), pp. 926-931, 2020.

[22] C.P.M. Neli, F. Fatmawaty and R. Hartono, "Acceptability and test the levels of protein and calcium in a cheese stick with the substitution of mackerel," Urban Health, vol. 2, no. (1), pp. 122-129, 2019.

[23] Y. Shen, L. Tebben, G. Chen and Y. Li, "Effect of amino acids on Maillard reaction product formation and total antioxidant capacity in white pan bread," International Journal of Food Science and Technology, vol. 54, no. (4), pp. 1-9, 2018.

[24] K.C. Mervina and S.A. Marliyati, "Formulasi Biskuit dengan Substitusi Tepung Ikan Lele Dumbo (Clarias gariepinus) dan Isolat Protein Kedelai (Glycine max) sebagai Makanan Potensial untuk Anak Balita Gizi Kurang," Jurnal Teknologi dan Industri Pangan, vol. 23, no. (1), pp. 9$16,2012$. 